Snežana Dević ${ }^{*}$, Mira Cocić

Scientific paper

ISSN 0351-9465, E-ISSN 2466-2585

UDC:669.141.25-147

${ }^{1}$ Institut IMS a.d, Beograd, Srbija, ${ }^{2}$ Univerzitet u Beogradu, Tehnički fakultet u Boru, Bor, Srbija doi: $10.5937 /$ ZasMat1702151D

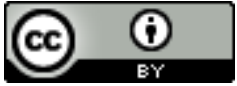

Zastita Materijala 58 (2)

$151-157$ (2017)

\title{
Submerge entry Nozzles based on alumo-graphite refractory material in the process of continuous steel casting
}

\begin{abstract}
Submerge entry Nozzles are parts made of refractory material and are utilized for steel casting in the continuous casting process. Steel is cast from the tundish into the crystallizer through the Submerge entry Nozzle (SEN). The role of the SEN is to protect steel from oxidation and to provide a uniform flow of steel during casting[1][2]. SEN are manufactured from refractory material with diverse composition. At the beginning of application of SEN, when introducing the continuous casting process, white SEN, based on melted quartz, were utilized.White SEN were utilized primarily for casting one steel grade.

Alumo-graphite SEN are another type of SEN that are utilized for casting all steel grades. They are sensitive to thermal shocks, so before use they must be heated in special heating facilities at the temperature ranging from $1000^{\circ} \mathrm{C}-1100^{\circ} \mathrm{C}$. Alumo-graphite SEN are manufactured by special isostatic pressing process. These are used successfully today. During casting, the SEN are in contact with steel on the internal side of the wall, and on the external side of the wall with casting powder and slag formed in the crystallizer. Internal erosion sometimes appears at the contact with steel on the internal side of the wall of alumo-graphite SEN, but build-up is formed more often. The SEN erosion occurs on the external side of the SEN wall, which originated due to the effect of casting powder and slag. All three phenomena affect SEN durability. External erosion reduces the thickness of SEN wall and causes SEN cracking. On the other hand, the formed build-up reduces the diameter of SEN orifice (aperture) leading to reduction of steel flow and excluding the SEN from the exploitation process. Depending on the steel grade being cast, mineralogical composition of casting powder, quality of alumo-graphite SEN, SEN design, technological parameters and technological process itself, the internal, external erosion or build-up will appear on the internal wall of the alumo-graphite SEN. Each of enumerated phenomena affects the lifetime of the alumographite SEN.This scientific paper aimed at presenting and explaining the phenomena and causes of reduced lifetime of the alumo-graphite SEN on a few characteristic examples.
\end{abstract}

Keywords: SEN (Submerge entry nozzle), alumo-graphite material, erosion, build-up.

\section{INTRODUCTION}

Submerge entry nozzles, the so-called SEN are very important parts of the nozzle equipment for continuous steel casting [1-2]. They are made from refractory material.

The alumo-graphite SEN are most often used. The SEN for continuous steel casting should have the following characteristics:

- Temperature stability in the temperature zone up to $1600^{\circ} \mathrm{C}$;

\footnotetext{
* $\overline{\text { Corresponding author: Snežana Dević }}$ E-mail: snezana.devic@institutims.rs Paper received: 03. 11. 2016.

Paper accepted: 15. 01. 2017.

Paper is available on the website: www.idk.org.rs/journal
}

- Low ability of chemical reacting of refractory material and liquid steel and alloying elements thereof;

- Resistance to erosion at high steel flow rates;

- Low porosity, for reducing the possibility of air penetration into steel;

- Low sensitivity to thermal shocks;

- To enable a stable casting process by its properties;

- Exact geometrical form;

- Economically justified price[1].

At continuous steel casting, the SEN enables a uniform steel flow from the tundish into the crystallizer and protects steel from oxidation. During exploitation the SEN is in contact with steel on the internal side of the wall. On the external side the SEN is partly (slag layer) in contact with casting 
powder and slag formed from casting powder. Depending on mineralogical-chemical composition of the casting powder, a stronger or weaker external SEN erosion occurs [3-8].

The steel, in contact with the SEN wall, can have a mechanical effect, when, due to high flow rate, it causes wear-out and abrasion, but also a chemical effect, when internal SEN erosion occurs [9]. At the occurrence of internal erosion, the internal nozzle diameter is increased. However, the formation of build-up occurs more often. The formed build-up reduces the internal SEN diameter, and thereby steel flow, which leads to exclusion of SEN from the casting process [10].

The macro appearance of the alumo-graphite SEN after exploitation is shown in Figurw 1 and 2.

\section{EXPERIMENTAL PART}

The experimental section included microscopic testing of a certain number of alumo-graphite SEN, on which external erosion occurred, that originated by the effect of casting powder with different composition or the appearance of build-up on the internal SEN wall. At the same time, microscopic testing of casting powders and build-up has been carried out.
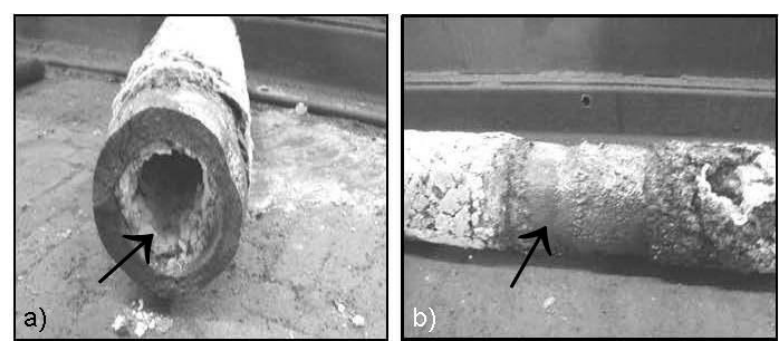

Figure 1.Macro appearance of the alumo-graphite

SEN after exploitation a)Build-up formed on the internal SEN wall; b)external SEN erosion

Slika 1.Makro izgled alumo-grafitnog SEN posle eksploatacije a) Nalep formiran na unutrašnjem zidu alumo-grafitnog izlivnika; b) spoljašnja erozija alumo-grafitnog izlivnika

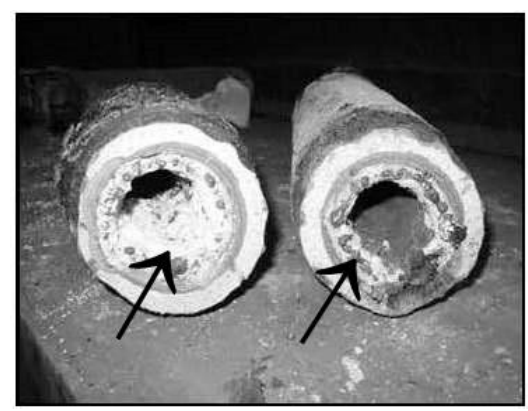

Figure 2.Macro appearance of the alumo-graphite SEN after exploitation (Build-up formed on the internal SEN wall)

Slika 2.Makro izgled alumo-grafitnog SEN nakon eksploatacije (Nalep formiran na unutrašnjem zidu izlivnika)
Microscopic testings were performed on the reflected or transmitted light microscope. Characteristic results of those testings have been selected and shown in this scientific paper.

\section{RESULTS AND DISCUSSION}

Build-up is formed on the internal side of the SEN wall. Inner build-up of alumo-graphite SEN are shown in Figure 3.
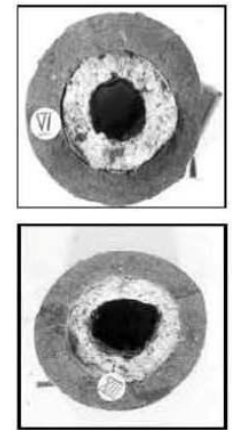
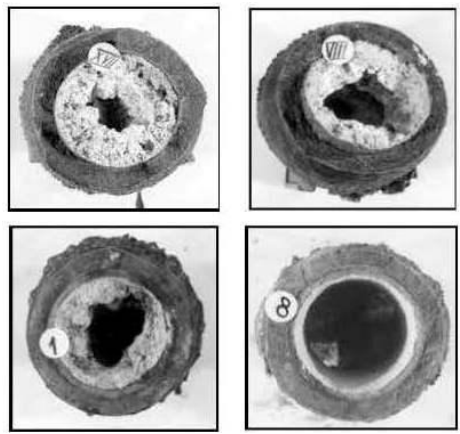

Figure 3.Macro appearance of SEN with build-up formed on the internal SEN wall, with the appearance of internal erosion

Slika 3. Makro izgled SEN sa nalepom formiranimna unutrašnjem zidu SEN, sa pojavom unutrašnje erozije

As it can be seen, the thickness of inner buildup of the SEN is different, and it ranges from $7 \mathrm{~mm}$ to $20 \mathrm{~mm}$. At the same time, the value of internal diameter of the SEN has been increased, which indicates that internal SEN erosion (Table 1) also occurred. The formation of build-up, in such cases, is, on one hand, the result of deoxidation and reoxidation of steel, and on the other hand, the result of reaction between the oxides from SEN material and the elements of steel composition.

A group of the presented SEN has been used at continuous casting of carbon steel and aluminum killed steel.

SEN are shown in Figure 4, but without the appearance of internal SEN erosion. The internal diameter of the SEN has not been changed but it retained the initial value (Table 2 ). The build-up, formed in the first two SEN, is only the result of steel deoxidation and reoxidation process. The oxides from SEN material did not take part in the formation of build-up on the internal side of the wall of these SEN. Phase composition of build-up has been determined by the polarization microscope (transmitted light) and by X-ray diffraction analysis (XRPD).The basic mineral in the composition of build-up is a Corundum.

In addition, there are most often minerals such as Hibonite $5 \mathrm{H}$ with the formula $\mathrm{CaO}_{3} \mathrm{Al}_{2} \mathrm{O}_{3} 3 \mathrm{Fe}_{2} \mathrm{O}_{3}$, Magnetite $\mathrm{FeOFe}_{2} \mathrm{O}_{3}$ and graphite $\mathrm{C}$. Calcium hexaaluminate $\mathrm{CaO} 6 \quad \mathrm{Al}_{2} \mathrm{O}_{3}$ can be sometimes found in the build-up, which is very similar to 
Corundum according to microscopic characteristics. Figure 5 shows the micro appearance of a build-up in the transmitted light microscope (immersion liquid, xilol). It can be seen on the figure that grain-like forms of aCorundum and irregular forms of hematite or magnetite are present in the build-up composition.
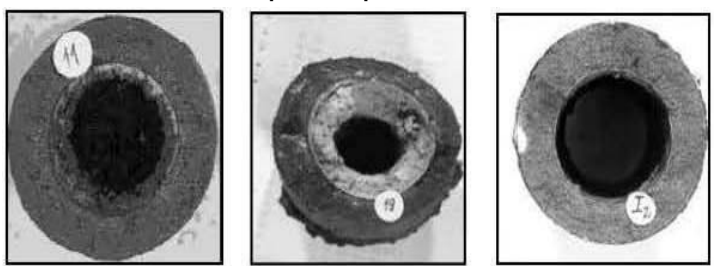

Figure 4.Macro appearance of SEN with build-up formed on the internal SEN wall, but without the appearance of internal erosion.

Slika 4. Makro izgled SEN sa nalepom formiranim na unutrašnjem zidu SEN, ali bez pojave unutrašnje erozije

Schematic presentation of the measurement of internal erosion of SEN wall is shown in Figure 6.

According to characteristics (color and form) in the transmitted light microscope, magnetite, graphite and hematite are very similar, therefore, for confirming the identification of these mineralogical phases the X-ray diffraction method is used.

The X-Ray diffractogram of the internal build-up of the SEN A8 (carbon steel) is shown in Fig. 7 and the X-Ray diffractogram of the internal build-up of the SEN B7 (aluminum killed steel) is shown in Fig. 8. Besides the values of the build-up thickness and internal erosion, the technological parameters, such as casting speed and casting time, are also shown in Tables 1 and 2.

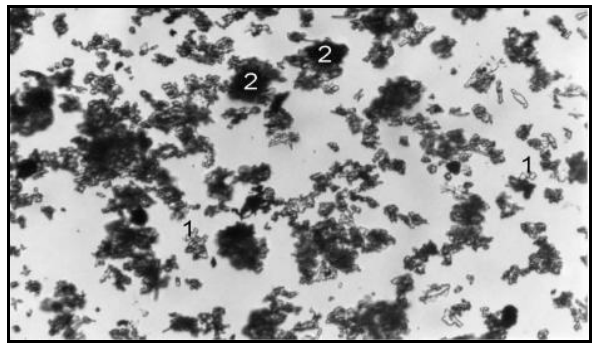

Figure 5.Micrograph of the build-up SEN (transmitted light-immersion, liquid xilol), 1- $\alpha$ corundum, 2-hematite

Slika 5.Mikro izgled nalepa izlivnika (propušteno svetlo-imerzija, tečnost xilol), 1- a korund, 2hematit

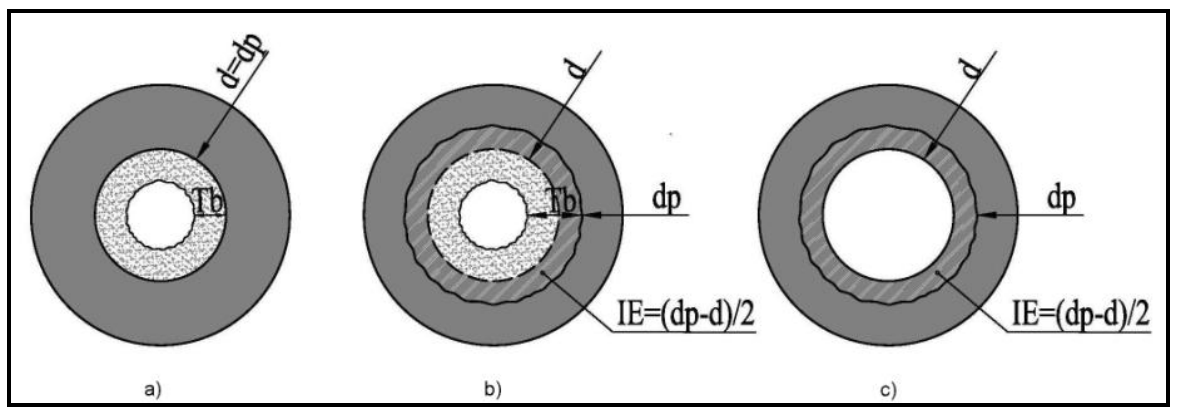

Figure 6.Schematic presentation of the measurement internal erosion of SEN; a)internal build-up of SEN without the appearance internal erosion, b) internal build-up of SEN with the appearance internal erosion, c)internal erosion of SEN

Slika 6. Šemetski prikaz merenja unutrašnje erozije SEN; a)unutrašnji nalep SEN bez pojave unutrašnje erozije b) unutrašnji nalep SEN sa pojavom unutrašnje erozije, c)unutrašnja erozija SEN

Table 1.Values of the build-up SEN and internal erosion of the alumo-graphite SEN

Tabela 1.Vrednosti unutrašnjeg nalepa SEN i unutrašnja erozija alumo-grafitnog SEN

\begin{tabular}{|l|c|c|c|c|c|c|c|}
\hline $\begin{array}{c}\text { Mark of } \\
\text { SEN }\end{array}$ & $\begin{array}{c}\text { Tb } \\
(\mathrm{mm})\end{array}$ & $\begin{array}{c}\mathrm{d} \\
(\mathrm{mm})\end{array}$ & $\begin{array}{c}\mathrm{dp} \\
(\mathrm{mm})\end{array}$ & $\begin{array}{c}\text { Internal Erosion of } \\
\text { SEN (dp-d)/2, (mm) }\end{array}$ & $\begin{array}{c}\text { Speed of formation } \\
\text { build-up, (mm/min) }\end{array}$ & $\begin{array}{c}\text { Casting } \\
\text { speed, } \\
(\mathrm{m} / \mathrm{min})\end{array}$ & $\begin{array}{c}\text { Casting } \\
\text { time, } \\
(\mathrm{min})\end{array}$ \\
\hline AVI & 15 & 70 & 73 & 1.5 & 0.057 & 0.79 & 263 \\
\hline AVIII & 15 & 70 & 80 & 5.0 & 0.061 & 0.65 & 245 \\
\hline AXVII & 20 & 70 & 75 & 2.5 & 0.087 & 0.80 & 237 \\
\hline B1 & 20 & 70 & 73 & 1.5 & 0.095 & 0.90 & 209 \\
\hline B7 & 13 & 70 & 75 & 2.5 & 0.073 & 0.72 & 178 \\
\hline
\end{tabular}

Legend: $d$ - internal diameter of the Alumo-graphite SEN before exploitation; $d p$ - internal diameter of the Alumographite SEN after exploitation; Tb- Thicknes of build-up

Legenda: $d$ - unutrašnji prečnik Alumo-grafitnog SEN pre eksploatacije; dp -unutrašnji prečnik Alumo-grafitnog SEN posle eksploatacije ; Tb- Debljina nalepa 
Table 2. Values of the build-up SEN without the appearance internal erosion

Tabela 2. Vrednosti nalepa SEN bez pojave unutrašnje erozije

\begin{tabular}{|c|c|c|c|c|c|c|c|}
\hline $\begin{array}{c}\text { Mark of } \\
\text { SEN }\end{array}$ & $\mathrm{Tb}(\mathrm{mm})$ & $\begin{array}{c}\mathrm{d} \\
(\mathrm{mm})\end{array}$ & $\mathrm{dp}(\mathrm{mm})$ & $\begin{array}{c}\text { Internal erosion } \\
\text { SEN, }(\mathrm{mm})\end{array}$ & $\begin{array}{c}\text { Speed } \\
\text { of formation build- } \\
\text { up, (mm/min) }\end{array}$ & $\begin{array}{c}\text { Casting } \\
\text { speed } \\
(\mathrm{m} / \mathrm{min})\end{array}$ & $\begin{array}{c}\text { Casting } \\
\text { time } \\
(\mathrm{min})\end{array}$ \\
\hline AXX & 3 & 70 & 70 & 0 & 0.032 & 0.85 & 94 \\
\hline B5 & 5 & 70 & 70 & 0 & 0.032 & 0.70 & 158 \\
\hline B19 & 14 & 70 & 70 & 0 & 0.061 & 1.00 & 229 \\
\hline B2 & 10.5 & 70 & 70 & 0 & 0.118 & 0.90 & 89 \\
\hline B11 & 6 & 70 & 70 & 0 & 0.033 & 0.85 & 181 \\
\hline
\end{tabular}

Table 3.Mineralogical composition of casting powders

Tabela 3.Mineraloški sastav livnih prahova

\begin{tabular}{|c|c|c|c|c|c|c|}
\hline $\begin{array}{c}\text { Mark of Casting } \\
\text { powder }\end{array}$ & $\begin{array}{c}\text { Wollastonite } \\
\mathrm{CaOSiO}_{2}\end{array}$ & $\begin{array}{c}\text { Quartz } \\
\mathrm{SiO}_{2}\end{array}$ & $\begin{array}{c}\text { Calcined lime } \\
\mathrm{CaO}\end{array}$ & $\begin{array}{c}\text { Graphite } \\
\mathrm{C}\end{array}$ & $\begin{array}{c}\text { Fluorite } \\
\mathrm{CaF}_{2}\end{array}$ & $\begin{array}{c}\text { Hematite } \\
\mathrm{Fe}_{2} \mathrm{O}_{3}\end{array}$ \\
\hline $\mathrm{MA}$ & + & + & & + & & + \\
\hline SRD-1 & & + & + & + & + & + \\
\hline SRD-2 & + & + & & + & + & + \\
\hline
\end{tabular}

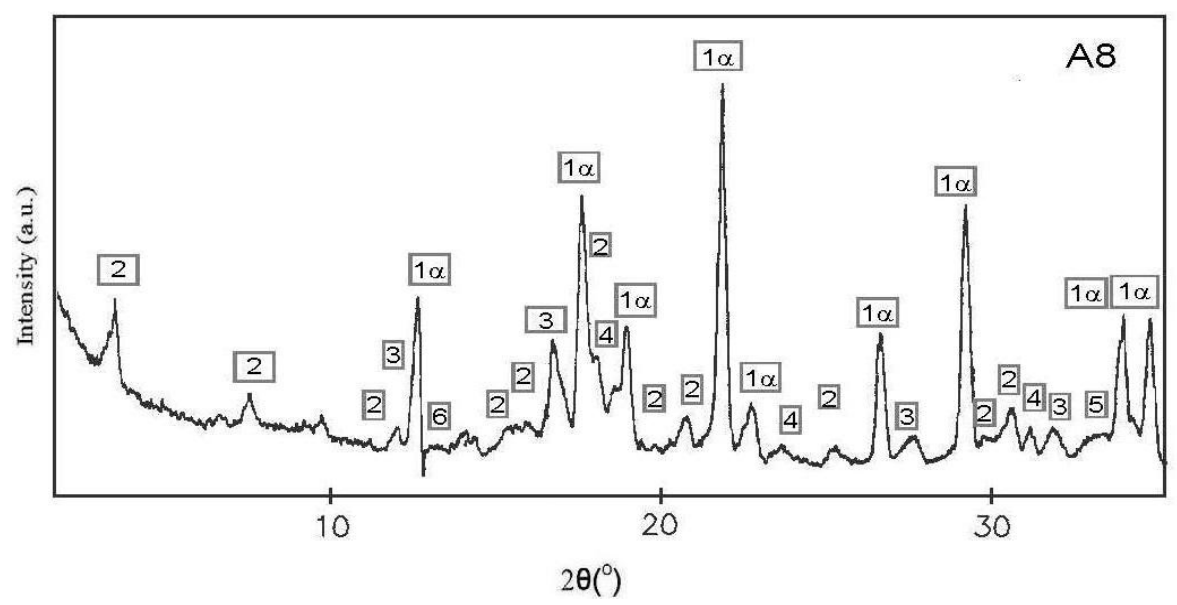

Figure 7.X-Ray diffractogram of the internal build-up of the SEN A8; 1a-corundum, 2-hibonite $5 \mathrm{H}$, 3hematite, 4-magnetite, 5-Fe, 6- graphite

Slika 7.Rendgenski difraktogram unutrašnjeg nalepa SEN A8; 1a-korund, 2-hibonit 5H, 3-hematit, 4magnetit, 5-Fe, 6- grafit

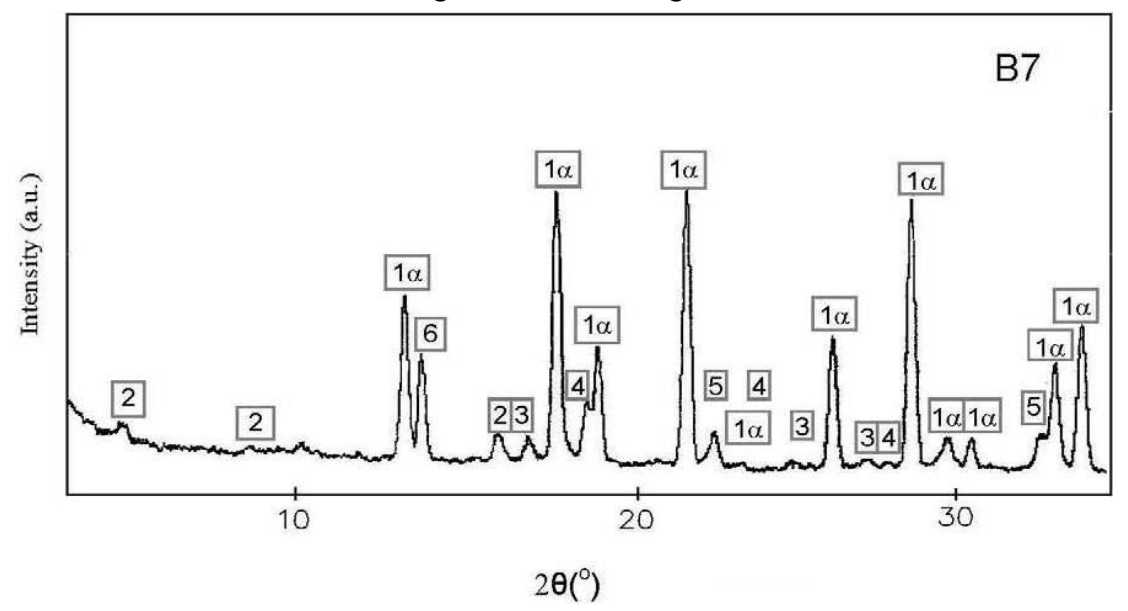

Figure 8.X-Ray diffractogram of the internal build-up of the SEN B7; 1 $\alpha$-corundum, 2-hibonite 5H, 3hematite, 4-magnetite, 5-Fe, 6- graphite

Slika 8.Rendgenski difraktogram unutrašnjeg nalepa SEN B7; 1 $\alpha$-korund, 2-hibonit 5H, 3-hematit, 4magnetit, 5-Fe, 6-grafit 
Alumo-graphite SEN are, during the continuous steel casting process, more or less intensively exposed to the effect of casting powder and its slag that was formed in the crystallizer. The result of this effect is the appearance of the external SEN erosion.

The appearance of the external SEN erosion is shown in Figure $1 \mathrm{~b}$. The casting powder is a polymineral material, mixture of several mineral components in a defined ratio. In contrast to powdery casting powder which is cheaper, the granulated casting powder is also used. The micro appearance of granulated casting powder is shown in Fig. 9, and mineralogical composition of three casting powders is shown in Table 3.

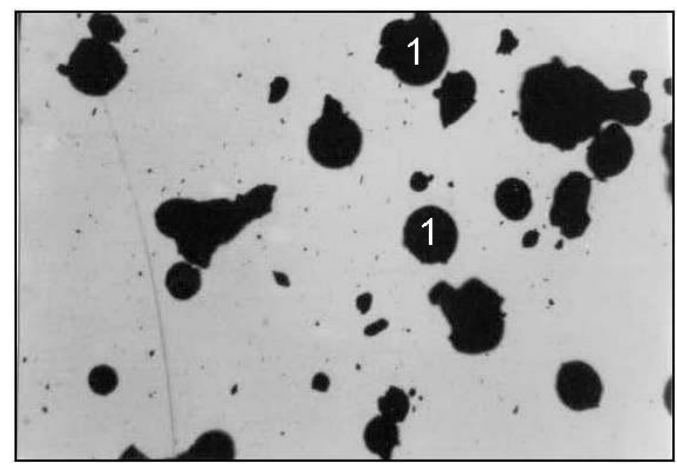

Figure 9.Micrograph of granulated casting powder (transmitted light), magnification x250; 1-granules

Slika 9.Mikro izgled granulisanog livnog praha (propušteno svetlo), Uvećanje x250; 1-granule

As it can be seen from Table 3 , in the casting powder composition there is most often quartz, fluorite, graphite, hematite, which is, at the same time, common for them. The thing that differentiates them is the presence or absence of wollastonite, calcite and some other mineral. The micro appearance of the casting powder containing plate-like forms of wollastonite and irregular forms of hematite and graphite is shown in Fig. 10.

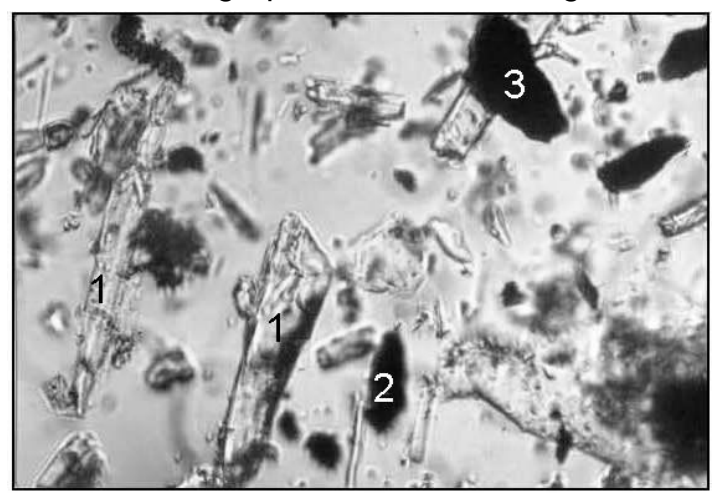

Figure 10.Micrograph of casting powder MA (transmitted light-immersion, liquid xilol)

1-wollastonite, 2-graphite, 3-hematite

Slika 10.Mikro izgled livnog praha MA (Propušteno svetlo-imerzija, tečnost xilol)

1-volastonit, 2-grafit, 3-hematit
The micro appearance of the casting powder SRD-1 is shown in Fig. 11, which caused a considerably higher external erosion of the alumo-graphite SEN than the casting powder SRD-2 shown in Fig. 12.

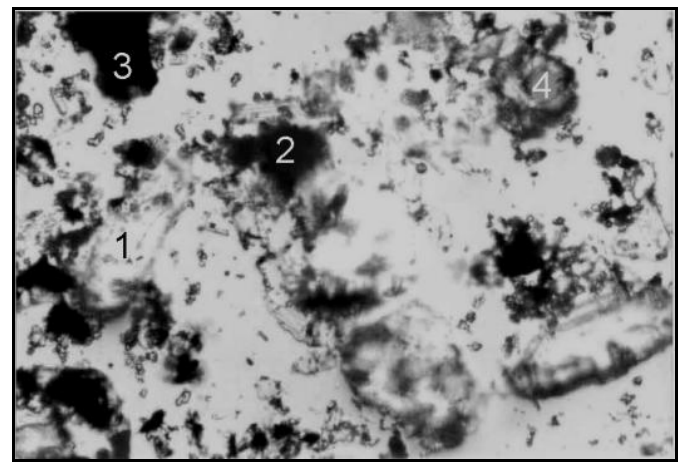

Figure 11.Micrograph of casting powder SRD-1 (transmitted light-immersion, liquid xilol), 1-quartz, 2-graphite, 3-hematite, 4- calcined lime

Slika 11.Mikro izgled livnog praha SRD-1 (propušteno svetlo-imerzija, tečnost xilol), 1-kvarc, 2-grafit, 3-hematit, 4-kalcinisani kreč

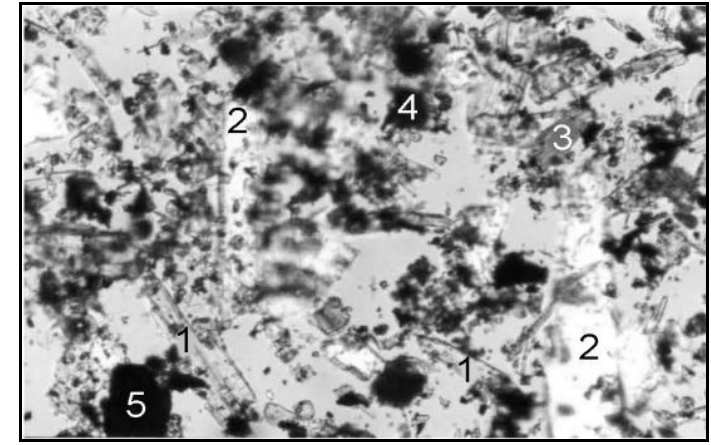

Figure 12.Micrograph of casting powder SRD-2 (transmitted light-immersion, liquid xilol)

1-wollastonite, 2- quartz, 3-fluorite, 4-graphite 5-hematite

Slika 12.Mikro izgled livnog praha SRD-2 (propušteno svetlo-imrzija, tečnost xilol) 1 volastonit, 2- kvarc, 3-fluorit, 4-grafit, 5-hematit

A decrease of external erosion of the alumographite SEN during the effect of casting powders containing the mineral wollastonite in the mineralogical composition has been recorded in plant and laboratory conditions. The external erosion of the alumo-graphite SEN is 2.5 times lower than the external erosion of the alumo-graphite SEN that were exposed to the effect of casting powder without wollastonite. The presence of wollastonite in the casting powder SRD-2 had a favorable effect on the decrease of erosion of the alumographite SEN.

The unchanged structure of the alumographite SEN (the middle of the wall) composed of grains of the primary corundum and graphite, in strip form, is shown in Figure 13. 


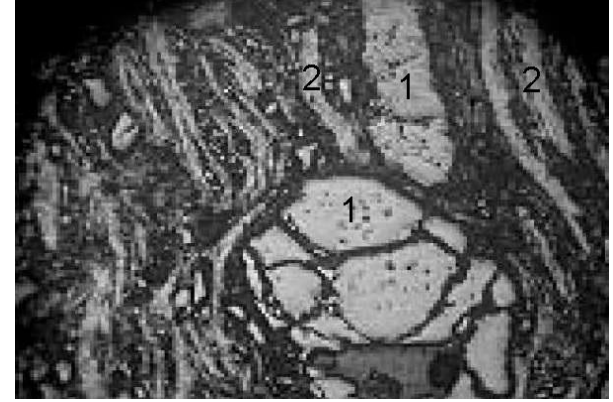

Figure 13.Micrograph of the structure alumographite SEN (middle wall of SEN), reflected light, magnification x250; 1-primary corundum, 2-graphite

Slika 13.Micro izgled strukture alumo-graphitnog SEN (sredina zida SEN), odbijeno svetlo, uvećanje x250; 1-primarni korund, 2-grafit

Figure 14 shows the structure of the wall of the alumo-graphite SEN (internal side of the wall on contact with steel). As it can be seen, the wall structure has been affected, and it consists of graphite strips, newly formed secondary corundum, silicate glass and steel inclusions.

The structure of the alumo-graphite SEN has been affected, due to the reaction of material oxides and steel elements, which brought about the internal erosion of the alumo-graphite SEN. In this way, the secondary corundum has been formed on the internal side of the wall, i.e. toward steel, which is, by form, very similar to calcium hexaaluminate $\mathrm{CaO} \cdot 6 \mathrm{Al}_{2} \mathrm{O}_{3}$.

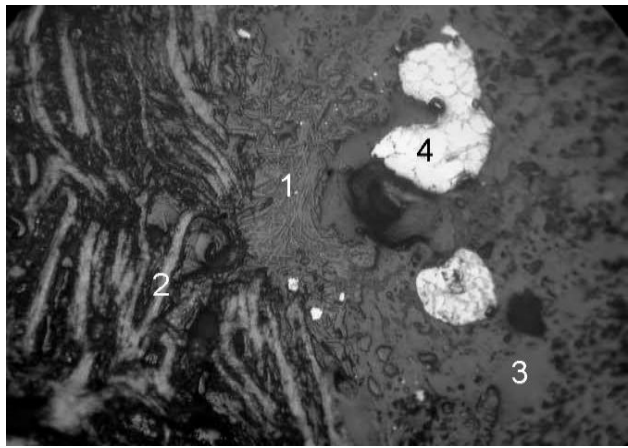

Figure 14.Micrograph of the structure alumographite SEN (contact by steel), reflected lightmagnification x250; 1-sekundary corundum, 2-

graphite, 3-silikate glass, 4-inclusion of steel

Slika 14.Mikro izgled strukture alumo-grafitnog SEN (kontakt s čelikom), odbijeno svetlo- uvećanje x250; 1-sekundarni korund, 2-grafit, 3-silikatno staklo, 4-uključak čelika

In contrast to internal erosion, the external erosion of the alumo-graphite SEN is a more frequent phenomenon. It occurs due to the effect of casting powder and slag from the crystallizer. If more aggressive casting powders are used during the continuous casting process, higher external erosion and shorter lifetime of the alumo-graphite SEN can be recorded. Fig. 15 shows the appearance of changed structure of the alumo-graphite SEN on contact with casting powder and slag. The primary corundum, graphite in strip form and spinnels in glassy slag are present in the structure.

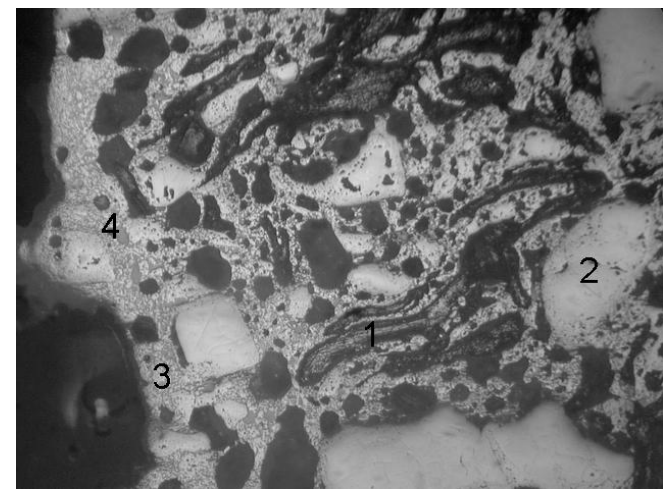

Figure 15.Micrograph of the structure alumographite SEN (contact by casting powder) reflected light-magnification x250; 1-graphite, 2primary corundum, 3-spinels, 4-glassy slag

Slika 15.Mikro izgled strukture alumo-grafitnog SEN (kontakt sa livnim prahom) odbijeno svetlouvećanje x250; 1-grafit, 2-primarni korund, 3spineli, 4-staklasta troska

\section{CONCLUSION}

Based on the presented in the scientific paper, a conclusion can be drawn that a decrease of the alumo-graphite lifetime is most often caused by external erosion and inner build-up.

External erosion is caused by the casting powder and slag being formed in the crystallizer. The intensity of external erosion of the alumographite SEN depends on the mineralogical composition of casting powder and slag, and thereby the lifetime of the same.

Inner build-up, as the second reason of decrease of the lifetime of the alumo-graphite SEN, are most often formed in the steel deoxidation and reoxidation process.

Also, build-up can be formed due to diffusion going on in the SEN material and reaction between the material oxides and steel components in the process of continuous steel casting.

This paper is a contribution to clarification of the role of SEN and phenomena that affect its service life in the casting process.

\section{REFERENCES}

[1] H.Lax (1980) Verwendung von feuerfesten Materialien in der Anlage zum kontinuierlichen Gießen von Stahl, XXIX Internationalen Konferenz über feuerfeste Material, Aachen.

[2] J.Panda, R.Das (1993) Refractories for continuous casting, Iron and Steel Review, pp.59-59. 
[3] F.Greeff, M. Watson (1984)Evolution and development of mold powders used in the continuous casting of steel, Mineralogy Applied, 34, 713-730.

[4] S. Dević, I. Živojinović, R. Carli, G. Faravelli (2002) Sen wearning experimental evidences of strong casting powder matrix effect, 4th European continuous casting Conference, Birmingham, $p$. $932-938$.

[5] S. Dević, L. Marčeta (2007) Erosion of submerged entry nozzles by casting powders, American Ceramic Society Bulletin, 86(6), $9101-9103$.

[6] S. Dević, R. Carli, (2007) Effect of wollastonite mineral $\mathrm{CaOSiO}_{2}$ content in continuous casting powder to SEN erosion, Key Engineering Materials, 352, $107-110$.
[7] Y.Nakamura, T.Ando, K.Kurata, M.lkeda (1986) Effecat of chemical composition of mold powder on the erosion of submerged nozzles for continuous casing of steel, Transactions ISIJ,.26,1052-1058

[8] K.Mukai, J.M.Toguri, N.M.Stubina, J.Yoshitomi (1989) A mechanism for the local corrosion of immersion nozzles, ISIJ International, 29,469-476.

[9] S.Dević,V.Jokanović, M.Logar (2006) The dependence of the SEN internal erosion and the concentration of $\mathrm{Al}, \mathrm{Si}$ and $\mathrm{Ca}$ in the SENwall on the continuous steel casting, Interceram, 55(3), 180-185.

[10] S.Dević (2006) Identification of Hibonite $5 \mathrm{~h}$ in characterization of inner SEN deposit, Steel Research Internatuonal, 77(7), 524-527.

\section{IZVOD}

\section{IZLIVNICI NA BAZI ALUMO-GRAFITNOG VATROSTALNOG MATERIJALA U PROCESU KONTINUIRANOG LIVENJA ČELIKA}

Izlivnici su oblikovani delovi od vatrostalnog materijala $i$ koriste se za livenje čelika u procesu kontinuiranog livenja. Čelik se lije iz međulonca u kristalizator kroz izlivnik. Uloga izlivnika je da štiti čelik od oksidacije i da obezbedi ravnomeran protok čelika pri livenju. Izlivnici se proizvode od vatrostalnog materijala različitog sastava.U početku primene izlivnika pri uvođenju postupka kontinuiranog livenja, korišćeni su beli izlivnici na bazi stopljenog kvarca. Beli izlivnici su korišćeni prvenstveno za livenje jedne vrste čelika. Alumo-grafitni izlivnici su druga vrsta izlivnika koji se koriste za livenje svih vrsta čelika. Osetljivi su na termošokove, pa se pre upotrebe moraju zagrevati u posebnim uređajima za zagrevanje na temperaturi od $1000^{\circ} \mathrm{C}-1100^{\circ} \mathrm{C}$. Alumo-grafitni izlivnici se proizvode posebnim postupkom izostatičkog presovanje. Ovi izlivnici se uspešno koriste $i$ danas. Izlivnici su pri livenju u kontaktu sa čelikom s unutrašnje strane zida, a sa spoljašnje strane zida sa livnim prahom i troskom formiranom u kristalizatoru. Na kontaktu sa čelikom na unutrašnjoj strani zida alumo-grafitnog izlivnika ponekad se javlja unutrašnja erozija, ali se češće formira nalep. Na spoljašnoj strani zida izlivnika javlja se erozija izlivnika nastala usled dejstva livnog praha $i$ troske. Sve tri pojave utiču na izdržljivost izlivnika. Spoljašnja erozija smanjuje debljinu zida izlivnika i izaziva pucanje izlivnika. Sa druge strane formirani nalep smanjuje prečnik otvora izlivnika što dovodi do smanjenja protoka čelika i izbacivanja izlivnika iz procesa eksploatacije.U zavisnosti od vrste čelika koji se lije, mineralnog sastava livnog praha, kvaliteta alumo-grafitnog izlivnika, dizajna izlivnika, tehnoloških parametara $i$ samog tehnološkog procesa pojaviće se unutrašnja, spoljašna erozija ili nalep na unutrašnjem zidu izlivnika. Svaka od nabrojanih pojava utiče na vek trajanja alumo-grafitnog izlivnika.Rad je imao za cilj da prikaže $i$ objasni na nekoliko karakterističnih primera pojave $i$ uzroke smanjenog veka trajanja alumografitnog izlivnika.

Ključne reči: izlivnici, alumo-grafitni materijal, erozija, nalep.

Naučni rad

Rad primljen: 03. 11. 2016.

Rad prihvaćen: 15. 01. 2017.

Rad je dostupan na sajtu: www.idk.org.rs/casopis

(c) 2017 Authors. Published by Inženjersko društvo za koroziju. This article is an open access article distributed under the terms and conditions of the Creative Commons Attribution 4.0 International license (https://creativecommons.org/licenses/by/4.0/) 